\title{
External morphological differences between Crepidostomum farionis and Crepidostomum metoecus (Trematoda: Allocreadiidae), parasites of salmonids, as revealed by SEM
}

\author{
František Moravec \\ Institute of Parasitology, Academy of Sciences of the Czech Republic, Branišovská 31, 37005 České Budějovice, Czech \\ Republic
}

Key words: Trematoda, Crepidostomum farionis, Crepidostomum metoecus, surface morphology, Salmo trutta, Czech Republic

\begin{abstract}
Scanning electron microscopy examinations of trematode specimens belonging to Crepidostomum farionis (O.F. Müller, 1784) and C. metoecus Braun, 1900, collected from brown trout, Salmo trutta fario L., in the Czech Republic, made it possible to study their surface morphology including details not described previously. The tegument of both species bears numerous characteristic papillae around the oral sucker (in C. metoecus also around the ventral sucker) and the ventral and dorsal surfaces of the forebody, exhibiting a high degree of variability in numbers and arrangement, with tegumental bosses forming lateral fields on the forebody and minute sensory receptors with submerged cilia scattered on the surface of the dorsal part of the oral sucker. In addition to marked differences in the size, shape and position of the oral muscular lobes, both species distinctly differ in the number of genital pores: two separate pores in C. farionis and a single pore in C. metoecus.
\end{abstract}

In European salmonids, trematodes of the genus Crepidostomum Braun, 1900 are represented mainly by two species, C. farionis (O.F. Müller, 1784) and $C$. metoecus Braun, 1900, that are also reported from palaearctic Asia and North America and the former also from North Africa (Ślusarski 1958a, Yamaguti 1971, Caira 1989). In Europe, both species are among the most common and widely distributed freshwater parasites of brown trout, Salmo trutta L., and other species of salmonids, frequently occurring in them in common infections. Occasionally they are found in cottids (Cottus spp.), balitorids [Barbatula barbatula (L.)] and some other fishes sharing the same environment with salmonids. Both species are morphologically rather similar and, as mentioned by Ślusarski (1958a, b) and Ergens (1963), in the past C. metoecus was frequently mistaken for C. farionis.

Ślusarski (1958a) and Ergens (1963) carried out a detailed comparison of the morphology of $C$. farionis and $C$. metoecus based on the light microscopical examinations of extensive materials from salmonids from the Vistula River basin and the South Baltic in Poland and from all three main river basins (the Rivers Elbe, Oder and Danube basins) in former Czechoslovakia. Ergens (1963) considered the following four characters to be reliable differentiating features: position of the cirrus sac opening relative to the caecal bifurcation; relative size of ventrolateral, dorsal and dorsolateral muscular oral lobes; size of the pharynx; and size ratio of the pharynx and the oral sucker.
A recent study (including scanning electron microscopy) by Choudhury and Nelson (2000) of Crepidostomum opeongoensis Caira, 1985, a parasite of North American hiodontids, has shown that surface morphology, especially the presence and distribution of various tegumental structures, may provide additional specific characters in trematodes of this genus. Because similar data on $C$. farionis and $C$. metoecus from European salmonids have not yet been published, both species have recently been examined by the scanning electron microscope (SEM) and the results obtained are presented herein.

\section{MATERIALS AND METHODS}

In this study, 10 gravid specimens of $C$. farionis and 10 gravid specimens of $C$. metoecus, both from the intestinal tract of brown trout, Salmo trutta fario L., were used; specimens of the former were collected from brown trout of the Rasnice River near Hniliště, southern Bohemia, on 27 June 2000, whereas those of the latter from the Homolský Brook in Velké Březno, northern Bohemia, on 16 August 2000; both streams are in the Czech Republic and belong to the Elbe River drainage system. After washing in physiological saline, the trematodes were fixed in hot $4 \%$ formaldehyde, postfixed in $1 \%$ osmium tetroxide, dehydrated though graded ethanol and acetone and then subjected to critical point drying. The specimens were sputter-coated with gold and examined with a JEOL JSM-6300 scanning electron microscope at an accelerating voltage of $15 \mathrm{kV}$. 


\section{RESULTS}

\section{Crepidostomum farionis (O. F. Müller, 1784)}

Figs. 1, 3 A-C

The body is elongate-oval, with the maximum width in the region of the ventral sucker. The tegument is unarmed, transversely striated. The anterior end bears the subterminal oral sucker provided with six muscular lobes ( 3 pairs); whereas the ventrolateral pair is formed by rather large, laterally oriented and in en face view almost triangular lobes distinctly projecting outward from the oral sucker (Fig. $1 \mathrm{~B}, \mathrm{C}$ ), both dorsal and dorsolateral pairs are formed by small, transversely oval papilla-like lobes not protruding or slightly protruding out from the body surface (Fig. 1 D, E, F); the latter may be very reduced as is visible in Fig. $1 \mathrm{D}$; lobes are rather far from each other. The bases of ventrolateral lobes are continuous with the inner margin of the dorsal part of the sucker, which appears to form a narrow but distinct edge (Fig. 1 E). The oral opening is oval.

The ventral sucker is approximately twice as large as the oral sucker, very broad, situated approximately at the border of the first and the second fourths of the body length. In all specimens studied the body region of the ventral sucker was markedly elevated, with a broad, slitlike opening situated transversely to the body axis (Fig. 1 A). No tegumental papillae were observed around this sucker. There is not one common genital pore, but the male and the female pores are distinctly separated, located close to each other (Fig. 3 B, C); the female pore is median, whereas the male one is situated obliquely anterior to the former (shifted to the left side); tegument around both genital pores may form two lateral elevations (Fig. $3 \mathrm{C}$ ) in some specimens. The genital pores are situated ventrally, slightly posterior to mid-line between the two suckers.

Three types of tegumental formations, papillae, bosses and minute sensory receptors with submerged cilia, were observed. The papillae are distributed around the oral opening and on the forebody (Fig. 1 A); no papillae were found in the acetabular region or on the hindbody. The papillae around the oral opening and on the forebody are numerous and are of two types, larger and smaller (Fig. 1 B, D, E). Although many of them are symmetrically arranged, there are many that are not and, apparently, a considerable variability exists in their numbers and arrangement. Nevertheless, there are always five characteristic larger papillae on the ventral and ventrolateral margin of the oral sucker and two pairs of papillae on the inner surface of the dorsolateral wall of the buccal cavity (Fig. $1 \mathrm{~B}$ ); as can be seen in Fig. $1 \mathrm{D}$ and $1 \mathrm{E}$, the arrangement and numbers of papillae on the dorsal and dorsolateral part of the oral sucker may differ considerably. The numerous tegumental papillae on the ventral side extend posteriorly to the level of the ventral sucker; on the dorsal side of the body they extend posteriorly approximately to the level of genital pores, but they are less numerous.

Tegumental bosses are weakly developed and are limited to two ventrolateral fields between ventrolateral oral lobes and sides of the ventral sucker (Fig. 1 A); no bosses were observed on the dorsal side of the body. Numerous minute sensory receptors appearing as pores under a lower magnification were found irregularly scattered on the terminal part of the oral sucker.

\section{Crepidostomum metoecus Braun, 1900}

Figs. 2, 3 D, E

The body is rather elongate, with the maximum width in the region of the ventral sucker. The tegument is unarmed, transversely striated. The anterior end bears the subterminal oval sucker provided with six marked muscular lobes arranged in three (ventrolateral, dorsal and dorsolateral) pairs; all lobes are approximately equal in size, large, rounded, distinctly projecting outward from the oral sucker (Fig. 2 B, E, F); lobes are close to each other. The bases (their anterior parts) of ventrolateral lobes are continuous with the inner margin of the dorsal part of the sucker, forming a narrow but distinct edge (Fig. 2 F). The oral opening is oval.

The ventral sucker is approximately of the same size as the oral sucker, being situated in about one fourth of the body length. The body region of the ventral sucker is elevated, the opening of the sucker is transversely oval (Fig. 3 D). The single genital pore (Figs. 2 A, 3 E) is situated ventrally, slightly posterior to mid-line between the two suckers.

Three types of tegumental formations, papillae, bosses and minute sensory receptors with submerged cilia, were observed. The papillae are distributed mainly around the oral sucker, the ventral sucker and on the ventral and dorsal surfaces of the forebody (Fig. 2 A, E). The papillae around the oral opening and on the forebody are of two types, larger and smaller (Fig. 2 A, E, F). Although many of them are symmetrically arranged, there are some asymmetrical papillae and the numbers of papillae are not identical in all specimens (compare, e.g., Figs. 2 B and 2 F). However, some of these papillae are always present; for example, there are always five characteristic larger papillae on the ventral and ventrolateral margin of the oral sucker and a pair of papillae on the inner surface of the dorsolateral wall of the buccal cavity (Fig. 2 A, F); as can be seen from Fig. $1 \mathrm{~A}$ and $1 \mathrm{E}$, the numbers of tegumental papillae on the ventral and dorsal sides of the body are not many and extend posteriorly to the level of the ventral sucker on the ventral side and to approximately the level of the genital pore on the dorsal side. There are six large papillae surrounding the ventral sucker (Fig. $3 \mathrm{D}$ ).

Tegumental bosses are well developed, numerous, forming two lateral fields a short distance posterior to the oral sucker and exceeding posteriorly the ventral sucker (Fig. 2 A, E). 


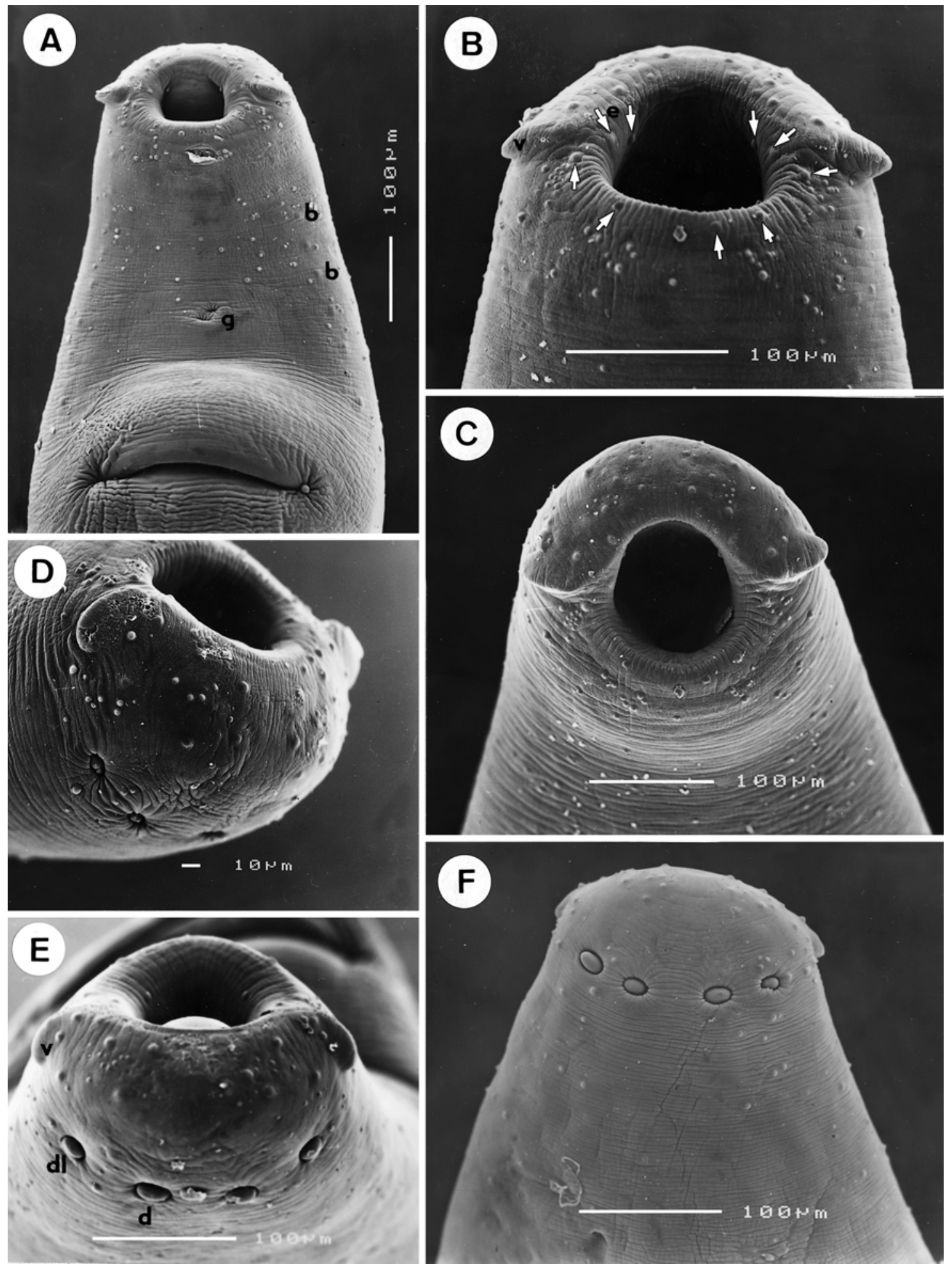

Fig. 1. Crepidostomum farionis (O.F. Müller, 1784), scanning electron micrographs of anterior part of body. A - distribution of tegumental papillae and bosses on ventral side of forebody; B, C - tegumental papillae around oral opening, ventral and subapical views (arrowheads show five characteristic larger papillae on ventral and ventrolateral margin of oral sucker and two pairs of papillae on inner surface of dorsolateral wall of buccal cavity); $\mathbf{D}$ - anterior end of specimen with considerably reduced dorsal and dorsoventral oral muscular lobes, sublateral view; $\mathbf{E}$ - anterior end of body, subdorsal view; $\mathbf{F}$ - distribution of dorsal and dorsolateral oral lobes and tegumental papillae on anterior end of body, dorsal view. $\mathrm{b}$ - tegumental boss; $\mathrm{d}$ - dorsal oral lobe; $\mathrm{dl}$ - dorsolateral oral lobe; $\mathrm{e}$ - edge of dorsal part of oral sucker; $\mathrm{g}$ - genital pores; $\mathrm{v}$ - ventrolateral oral lobe. 


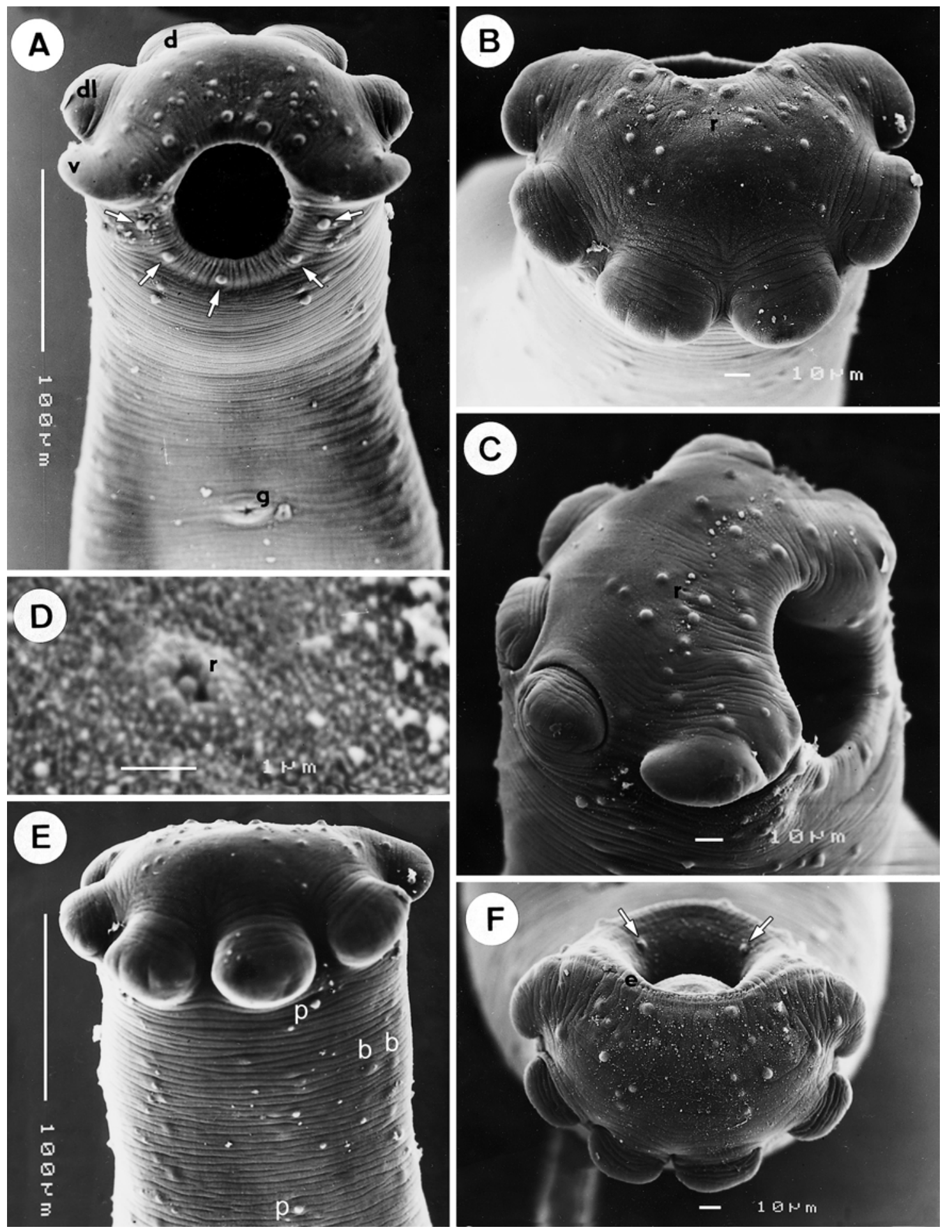

Fig. 2. Crepidostomum metoecus Braun, 1900, scanning electron micrographs of anterior part of body. A - distribution of tegumental papillae around oral opening and on ventral side of forebody (arrowheads show five characteristic larger papillae on ventral and ventrolateral margin of oral sucker); B, C - anterior body end with marked oral muscular lobes, two types of tegumental papillae and sensory receptors, apical and sublateral views; D - sensory receptor with submerged cilium; E distribution of tegumental papillae and bosses on dorsal side of anterior end of body, dorsal view; $\mathbf{F}$ - apical view of another specimen with different number and arrangement of tegumental papillae on dorsal part of oral sucker (arrowheads show a characteristic pair of papillae on inner surface of dorsolateral wall of buccal cavity). b - tegumental boss; $d$ - dorsal oral lobe; $\mathrm{dl}$ - dorsolateral oral lobe; $\mathrm{e}$ - edge of dorsal part of oral sucker; $\mathrm{g}$ - genital pore; $\mathrm{p}$ - tegumental papilla; $\mathrm{r}$ - sensory receptor with cilium; $v$ - ventrolateral oral lobe. 

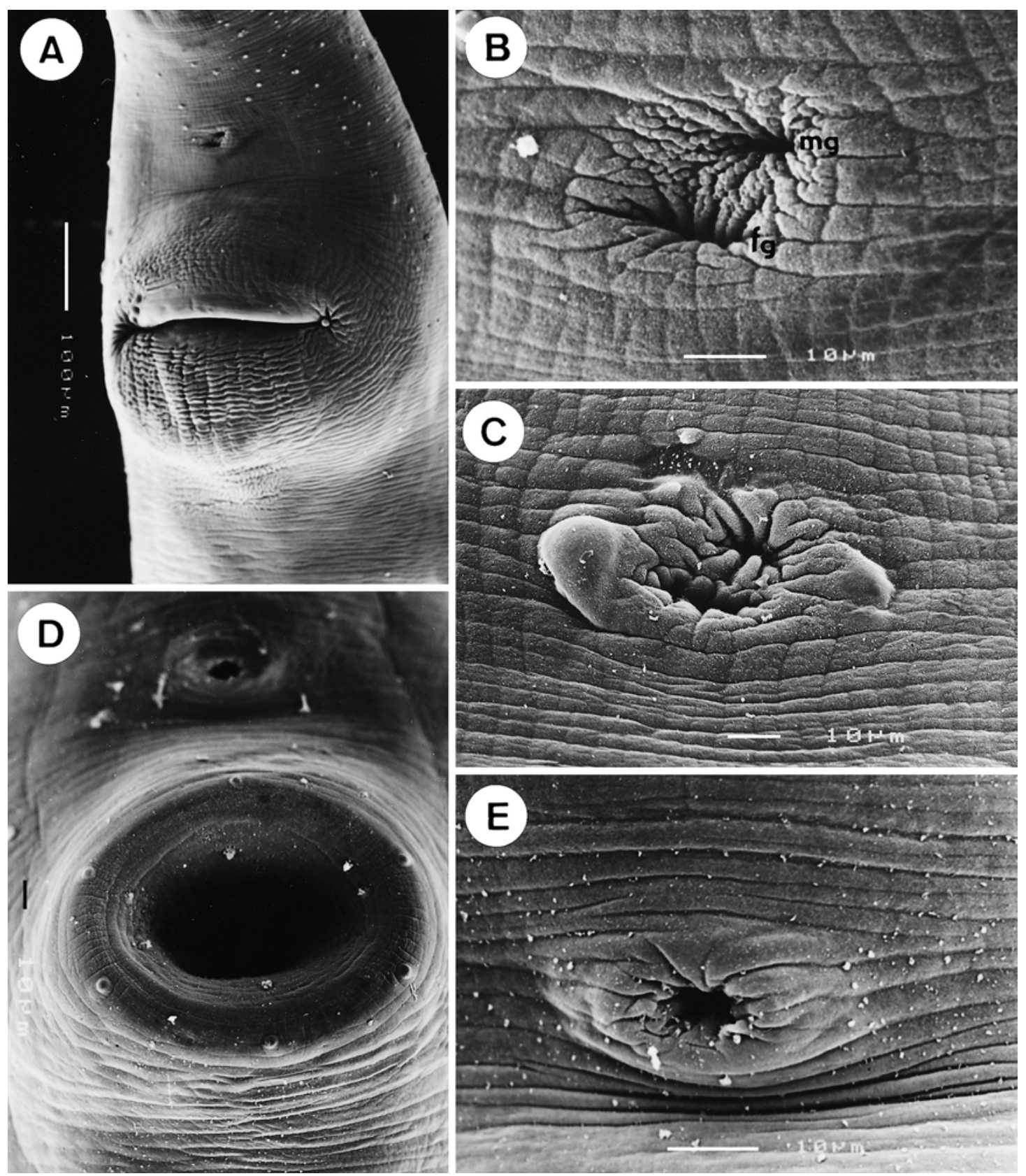

Fig. 3. A-C - Crepidostomum farionis (O.F. Müller, 1784) (A - middle part of body with ventral sucker, distinct genital pores and tegumental papillae, ventral view; B - genital pores; C - genital pores with lateral elevations of tegument); D, E Crepidostomum metoecus Braun, 1900 (D - region of genital pore and ventral sucker; E - genital pore); scanning electron micrographs. fg - female genital pore; $\mathrm{mg}$ - male genital pore.

Many minute sensory receptors appearing as pores under a lower magnification were found irregularly scattered on the terminal part of the oral sucker (Fig. 2 B); a higher magnification revealed the presence of a typical cilium surrounded by the elevated tegument (Fig. 2 D).

\section{DISCUSSION}

Although studies on Crepidostomum spp. based on light microscopy have a long and rich history (see Ślusarski 1958a, Skryabin and Koval 1966), the taxonomy of this genus including many nominal species 
parasitic mainly in freshwater fishes is unsatisfactory and the species identification is complicated by insufficient knowledge of the morphology of these forms. Until Ślusarski (1958a) provided detailed redescriptions of Crepidostomum farionis and C. metoecus, probably the only two species of this genus parasitising salmonids in Europe, these two were frequently confused and, consequently, many earlier published data on the geographical distribution, hosts and biology of $C$. farionis are unreliable, because, in fact, they may either completely or partly concern the more frequent $C$. metoecus.

It has been mentioned that Ślusarski (1958a) and Ergens (1963) carried out a detailed morphometrical comparison of these two species based on light microscopical examinations, oriented mainly to the internal structure of the worms. The present study shows that there are additional differences in the superficial structures of these species visible by SEM not previously reported

The SEM study confirmed the previous observations by Ślusarski (1958a) and some subsequent authors that the morphology (size, shape, location) of oral muscular lobes is conspicuously different in these two species and is one of the best interspecific differentiating features.

A very important interspecific difference found now by SEM is that there are two separate genital pores in $C$. farionis, whereas only a single genital pore (opening of a common genital atrium) is found in C. metoecus. The presence of a single genital pore is stated in the generic diagnoses of Crepidostomum given by Hopkins (1933), Skryabin and Koval (1966) and Yamaguti (1971) and in the description of $C$. farionis provided, e.g., by Nicoll (1909). According to Ślusarski (1958a), C. farionis possesses a pocket-like genital atrium, although he illustrated two (male and female) separate genital pores opening directly to the body surface.

To date, there are almost no data on the tegumental structures in Crepidostomum spp. In her revisionary work dealing with North American papillose Allocreadiidae, Caira (1989) provided scanning electron micrographs of the anterior end of eight North American Crepidostomum spp. including $C$. farionis and $C$. metoecus (these two based on specimens from British Columbia, Canada), mentioning the presence of tegumental papillae in them. Choudhury and Nelson (2000) found by SEM that the North American species Crepidostomum opeongoensis possessed three types of tegumental structures: tegumental papillae (around the oral and ventral suckers and on the ventral and dorsal surfaces of the body), tegumental bosses (on the dorsal surface of the forebody), and minute pores of subtegumental ducts (on ventral oral lobes and along edges of dorsolateral and dorsal lobes).
In this study, tegumental papillae and bosses were found in both $C$. farionis and $C$. metoecus. The papillae are more numerous in $C$. farionis as compared to those in $C$. metoecus. In both species they extend posteriorly to the level of the ventral sucker on the ventral side and to the level of the genital pores on the dorsal side. In contrast to what was found in $C$. opeongoensis, the tegumental papillae in both congeneric European species are much more numerous, highly variable in their numbers and arrangement, although some papillae are paired or have a characteristic position around the oral sucker; this intraspecific variability is also apparent when scanning electron micrographs of conspecific North American specimens (Caira 1989) are compared to those of the present European material; characteristic six papillae around the ventral sucker found in $C$. metoecus were not observed in $C$. farionis. Five large papillae around the ventral side of the oral sucker were present both in the two European species studied and in C. opeongoensis (Choudhury and Nelson 2000).

The tegumental bosses were poorly developed in $C$. farionis and better developed in C. metoecus, in both species forming two lateral fields on the forebody, extending slightly to ventral and dorsal sides. In contrast, bosses in $C$. opeongoensis are on the dorsal surface (Choudhury and Nelson 2000).

The series of closely-set openings of subtegumental ducts were not observed in C. farionis and C. metoecus, but their presence on the anterior edge of the dorsal part of the oral sucker cannot be excluded in these species. On the other hand, minute sensory receptors with submerged cilia, which appear as pores, were found irregularly scattered on the dorsal part of the oral sucker in both species. As far as the author knows, these receptors were not previously found in adult Crepidostomum spp., although they have recently been reported in the cercaria of a Crepidostomum sp. by Bogéa and Caira (2001).

Acknowledgements. The author's thanks are due to the management of the Board of the National Park and Protected Landscape Šmava in Vimperk and to the Association of Czech Fishermen in Ústí nad Labem for permission to carry out ichthyoparasitological investigations in the respective localities. The author is also grateful to the staff of the Laboratory of Electron Microscopy of the Institute of Parasitology, ASCR, in České Budějovice for their technical assistance and to Mrs. I. Husáková from the Laboratory of Helminth Biology of the same Institute for her help with the preparation of illustrations. Prof. J.N. Caira from the University of Connecticut (USA) kindly provided a copy of her revisional publication on North American papillose allocreadiids. This study was supported by the grant No. 524/ 00/0267 from the Grant Agency of the Czech Republic. 


\title{
REFERENCES
}

BOGÉA T., CAIRA J.N. 2001: Ultrastructure and chaetotaxy of sensory receptors in the cercariae of a species of Crepidostomum Braun, 1900 and Bunodera Railliet, 1896 (Digenea: Allocreadiidae). J. Parasitol. 87: 273-286.

CAIRA J.N. 1989: A revision of the North American papillose Allocreadiidae (Digenea) with independent cladistic analyses of larval and adult forms. Bull. Univ. Nebraska State Mus. 11: 1-58 + 195 Figs.

CHOUDHURY A., NELSON P.A. 2000: Redescription of Crepidostomum opeongoensis Caira, 1985 (Trematoda: Allocreadiidae) from fish hosts Hiodon alosoides and Hiodon tergisus (Osteichthyes: Hiodontidae). J. Parasitol. 86: 1305-1312.

ERGENS R. 1963: Revision of the helminth fauna of fishes from the territory of Czechoslovakia I. Genus Crepidostomum Braun 1900 (Trematoda: Allocreadiidae). Čs. Parasitol. 10: 81-88. (In Czech, German summary.)

HOPKINS S.H. 1933: The morphology, life histories and relationships of the papillose Allocreadiidae (Trematoda). (Preliminary report.) Zool. Anz. 103: 65-74.
NICOLL W. 1909: Studies on the structure and classification of the digenetic trematodes. Q. J. Microsc. Sci. 53: 391487.

SKRYABIN K.I., KOVAL V.P. 1966: Family Bunoderidae Nicoll, 1914. In: K.I. Skryabin (Ed.): Trematodes of Animals and Man. Essentials of trematodology 22. Nauka, Moscow, pp. 311-456. (In Russian.)

ŚLUSARSKI W. 1958a: The adult Digenea from Salmonidae of the basin of the Vistula and of the South Baltic. Acta Parasitol. Pol. 6: 247-528.

ŚLUSARSKI W. 1958b: Distribution of two species of the genus Crepidostomum Braun, 1900 (Digenea: Allocreadiidae) from Salmonidae in the basin of Vistula. Wiad. Parazytol. 4: 647-650.

YAMAGUTI S. 1971: Synopsis of Digenetic Trematodes of Vertebrates, I, II. Keigaku Publishing Co., Tokyo, 1074 pp. +349 Plts.

\section{GIBSONNEMA NOM. N., A NEW NAME FOR THE NEMATODE GENUS PARASEURATOIDES MORAVEC, SALGADO-MALDONADO ET AGUILAR- AGUILAR, 2002}

\author{
František Moravec $^{1,3}$, Guillermo Salgado-Maldonado ${ }^{2}$ and Rogelio Aguilar-Aguilar ${ }^{2}$ \\ ${ }^{1}$ Institute of Parasitology, Academy of Sciences of the Czech Republic, Branišovská 31, 37005 České Budějovice, Czech \\ Republic; \\ ${ }^{2}$ Institute of Biology, National Autonomous University of Mexico, A.P. 70-153, 04510 Mexico, D.F., Mexico; \\ ${ }^{3}$ Corresponding author
}

We have found that the generic name Paraseuratoides Moravec, Salgado-Maldonado et Aguilar-Aguilar, 2002 is a junior homonym to Paraseuratoides Wang, 1984. Therefore, a new name, Gibsonnema nom. n., is proposed to replace it (the new genus is named in honour of David I. Gibson, a wellknown English helminthologist).

These two genera are monotypic, belonging to the seuratoid family Quimperiidae Gendre, 1928, and both their type species are parasitic in swamp-eels (Synbranchidae, Synbranchiformes). However, they are well separated morphologically. In contrast to Gibsonnema, the genus Paraseuratoides is characterised mainly by a toothless buccal cavity, a bulbously inflated anterior end of the oesophagus and the presence of caudal alae in the male.

\section{References}

Moravec F., Salgado-Maldonado G., Aguilar-Aguilar R. 2002: Two new nematodes, Paraseuratoi-des ophisterni gen. et sp. n. (Quimperiidae) and Philo-metra ophisterni sp. n. (Philometridae), from the swamp-eel Ophisternon aenigmaticum in Mexico. Folia Parasitol. 49: 109-117.

Wang P.-q. 1984: Some nematodes of fishes from Fujian Province, China. Acta Zootaxon. Sin. 9: 228-237. (In Chinese, Engl. summary.)

Accepted 30 July 2002 